
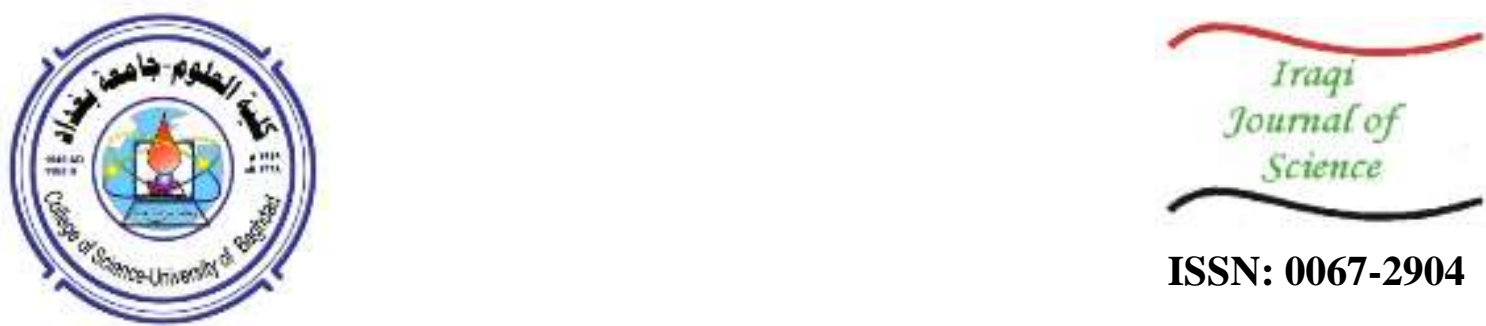

ISSN: 0067-2904

\title{
Palynofacies and Source Rocks Evaluation for Selected Samples of Subba Oil Field, Southern Iraq
}

\author{
Hussein A. Chafeet ${ }^{1 *}$ Nawfal A. Dahham ${ }^{1}$, Amna M. Handhal ${ }^{2}$ \\ ${ }^{1}$ Department of Oil and Gas Engineering, College of Oil and Gas Engineering, Basrah University for Oil and \\ ${ }^{2}$ Department of Geology, College of Science, University of Basrah, Basrah, Iraq
}

Received: 26/8/2019 Accepted: 22/10/2019

\begin{abstract}
This study includes a palynological and organic geochemical evaluation of Nahr Umr, Zubair, and Yamama Formations in the Subba field, Southern Iraq, represented by three wells (Su-14, Su-9 and $\mathrm{Su}-8$ ). The determination of quantity organic matter showed that the rocks of Nahr Umr Formation had a total organic carbon of $4.76 \%$, indicating very good production of hydrocarbons where type (II) kerogen was dominant, but the rocks were thermally immature. Zubair Formation had a total organic carbon of $1.91 \%$ to $2.26 \%$, indicating good to very good production of hydrocarbons where kerogen of types (I) and (II/III) were dominant, with low thermal maturity. Yamama Formation showed a total organic carbon of $1.68 \%$, revealing good production of hydrocarbons where type (I) kerogen was dominant, with low thermal maturity. Facies analysis of Nahr Umr, Zubair and Yamama Formations demonstrated the presence of two facies, namely the distal dysoxic-Oxic shelf and the distal suboxic-Anoxic basin. It is clear that the environment of rock deposition is a marine environment, which is far from the coast.
\end{abstract}

Keywords: Palynofacies, Source Rocks, Paleoenvironment, Geochemical Analyses, Subba oil field.

\section{السحنات البالينولوجية وتقييم الصخور المصدرية لنماذج مختارة من حقل صبة النفطي، جنوبي العرق}

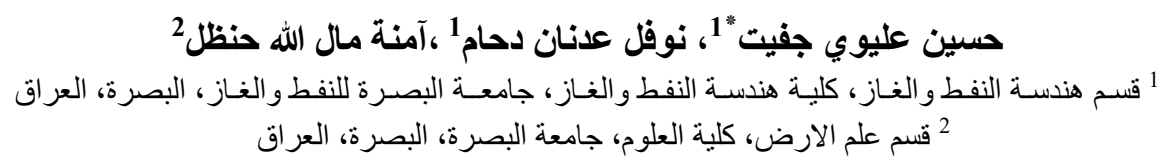

تناولت هذه الدراسة دراسة جيوكيميائية وبالينولوجية لتكاوين نهر عمر ، الزبير واليمامة في حقل صبة، جنوبي العراق تمثلت في ثلاث آبار هي (صبة-14، صبة-9 وصبة-8) وإثتملت هذه التحاليل على تحديد

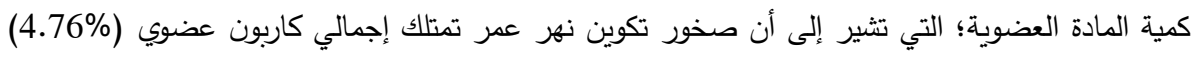
والذي يشير الى إن الصخور جيدة جداً لإنتاج الهيدروكاربونات، والنوع الثاني من الكيروجين هو السائد، ولكنها

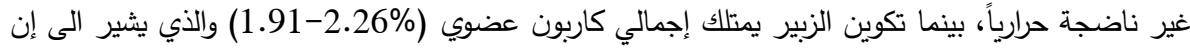

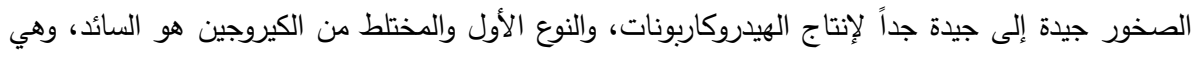

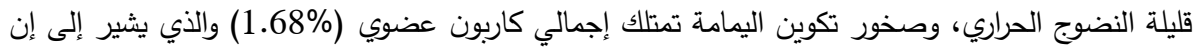
الصخور جيدة لإنتاج الهيدروكاربونات، ويغلب عليها النوع الأول من الكيروجين وهي قليلة النضون النيامي الحراري 


$$
\begin{aligned}
& \text { أيضاً.وأظهر التحليل السحني لتكاوين نهر عمر، الزبير واليمامة وجود سحنتين إشتملت على: } \\
& \text { 1 . سحنة الرف شبه المختزل - المؤكسدة البعيدة. } \\
& \text { 2. سحنة الحوض شبه المؤكسد - الاختزالي البعيد. }
\end{aligned}
$$

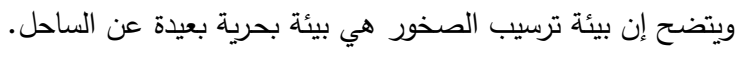

\section{Introduction}

The study area consists of three wells, namely Subba 14, 9 and 8, which lie within the Subba oil field. This study is presented in two parts; the first part includes a geochemical analysis of the kerogen in the stratigraphic column of the formations in the wells. The second part focuses on the shapes of spores, dinoflagellate, pollens...etc. as well as the shapes of sedimentary organic matters present within the kerogen of the source rocks. These are resistant to various biological, physical and chemical processes to keep their shapes within the liquid hydrocarbons.

Different sorts of organic matter yield different sorts of petroleum. Organic matter rich in soft and waxy tissues, such as that found in algae, commonly yield oil with associated gas on maturation (heating), while gas alone tends to be derived from the maturation of woody tissues. Even oil-prone source rocks yield gas when elevated to high temperatures during burial.

The presence of insoluble organic matter (kerogen) is a primary requisite for an active or a potential source rock. A potential source rock is one that is too immature to generate petroleum in its natural setting but will form significant quantities of petroleum when heated in the laboratory or during deep burial. An effective source rock is one that has already formed and expelled petroleum to a reservoir.

In this study, Nahr Umr, Zubair and Yamama Formations were selected to classify their content of organic matter through a detailed study, given that the rocks of these formations were deposited in Iraq during Middle and Lower Cretaceous [1].

Sedimentary organic matters and their relationship to the formation of oil were also analyzed to determine the age of source rocks. For this purpose, samples of rocks from three drilled wells were selected to obtain information of biological and geochemical specifications of deep layers and to determine the source rocks of oil and the relationship with their accumulation.

\section{Area of study}

This research depends on information gathered from the study area (Figure-1), where the samples were taken from Subba field located in Thi-Qar Governorate, southern Iraq. The field is located $70 \mathrm{~km}$ south-east of Nasiriyah city, 30km north of Luhais field and $40 \mathrm{~km}$ north-west of Ratawi field. Modern structural image shows that the field is a $30 \mathrm{~km}$ long and $8.7 \mathrm{~km}$ wide convex fold, with an axis trending to north-south. Coordinates of the studied wells are shown in Table-1.

Table 1- Coordinates of the studied wells.

\begin{tabular}{|c|c|c|}
\hline Well No. & Latitude & Longitude \\
\hline Subba -14 & $30^{\circ} 37^{\prime} 30^{\prime \prime} \mathrm{N}$ & $46^{\circ} 43^{\prime} 4 " \mathrm{E}$ \\
\hline Subba -9 & $30^{\circ} 34^{\prime} 50^{\prime \prime} \mathrm{N}$ & $46^{\circ} 42^{\prime} 52^{\prime \prime} \mathrm{E}$ \\
\hline Subba -8 & $30^{\circ} 32^{\prime} 14^{\prime \prime} \mathrm{N}$ & $46^{\circ} 45^{\prime} 10^{\prime \prime} \mathrm{E}$ \\
\hline
\end{tabular}




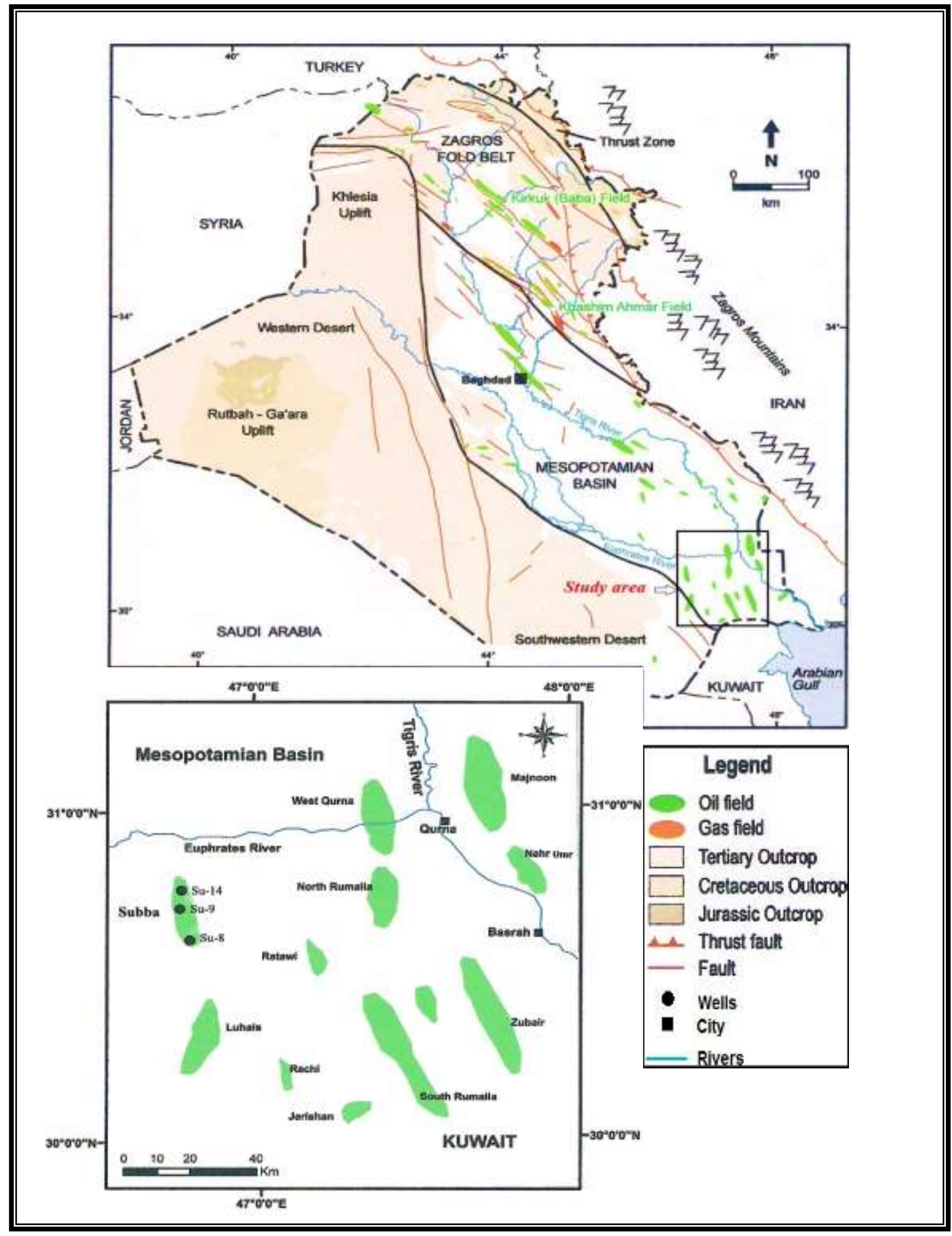

Figure 1- Main oil and gas fields in Iraq with the studied wells location [2]

\section{Methodology}

\section{Sampling}

Core samples for Nahr Umr, Zubair and Yamama Formations from Subba oil field (Su-14, Su-9 and $\mathrm{Su}-8$ ) are show in Table-2. 
The study also depends on basic references, e.g., final reports of wells [3] in addition to some previous studies about Lower Cretaceous source rocks in south Iraq and Nahr Umr, Zubair and Yamama Formations inside the area of study itself.

\section{Palynological study}

1. The palynological analysis applied to different core samples of the formations and source rocks was performed according to published standard methods [4, 5]. Table-2 shows the sequence of the following steps; Samples were grinded and sieved to a grain size of $2 \mathrm{~mm}$, then placed in a polyethylene container with 1 liter of diluted HCL acid. The container was left for one day to dissolve the carbonates in the sample. The sample was covered to prevent contamination. Thereafter, concentrated HCL acid was gradually added to avoid disintegration of samples.

2. The sample was left for two days to dissolve the carbonates. During pouring of the acid, consideration was taken not to lose the sample in the water pool. Water was added to dilute the poured acid, then distilled water was added and the sample was left for five hours to precipitate the organic matters. This process was repeated five times until the sample was neutralized, which could be tested using litmus papers. HF acid was added to the sample after total pouring out of water in a gradual way, then the sample was left longer than before to dissolve the silica. The acid was then neutralized by adding a basic material and poured out of the water pool before distilled water was added. This process was repeated five times until the sample was neutralized.

Table 2- Results of the analyses of rock samples; (1) Palynological analyses in the laboratories of the Geology Department, (2) Geochemical analyses at GeoMark Research Inc., Houston, U.S.A.

\begin{tabular}{|c|c|c|c|c|c|}
\hline Sample No. & Formation & Sample Type & Well No. & Depth (m) & $\begin{array}{c}\text { Kind of } \\
\text { analysis }\end{array}$ \\
\hline 1 & Nahr Umr & Core & Su-14 & 2562 & $\mathbf{1 , 2}$ \\
\hline 2 & Zubair & Core & Su-9 & 2767 & $\mathbf{1 , 2}$ \\
\hline 3 & Zubair & Core & Su-9 & 2775 & $\mathbf{1 , 2}$ \\
\hline 4 & Zubair & Core & Su-9 & 2780.5 & $\mathbf{1}$ \\
\hline 5 & Zubair & Core & Su-9 & 2784.5 & $\mathbf{1}$ \\
\hline 6 & Yamama & Core & Su-8 & 3585 & $\mathbf{1 , 2}$ \\
\hline 7 & Yamama & Core & Su-8 & 3622 & $\mathbf{1}$ \\
\hline 8 & Yamama & Core & Su-8 & 3669 & $\mathbf{1}$ \\
\hline
\end{tabular}

3. Next, the sample was moved into a glass container inside an ultrasonic instrument to prevent the gathering of the organic matter, then transferred into another container, a process which was repeated many times to eliminate heavy precipitated materials. After sieving with a 20-micron sieve to eliminate smaller size materials, the rest is put in a small bottle and closed tightly.

4. The organic matters was drawn from the 20-micron sieve by a dropper after adding cellulose by a test tube and mixing it. The materials were then spread on a glass cover and left for 24 hours. The cover was attached to a thicker one by Canada balsam, after which the slide was ready to be studied.

\section{Geochemical Organic Analyses \\ Total organic carbon (TOC)}

The level of TOC can be approximately evaluated, but its ratio and degree of preservation in the sedimentary basin are affected by many factors such as sedimentary environment, rate of deposition, proximity or distance from the coastline, evaporation quantity, and ratio of re-deposition [5, 6].

To measure the TOC in sediments, which form oil, the LeCO method was applied in the laboratories of GeoMark Research Inc., USA.

The geochemical results in Table-3 reveal that Nahr Umr Formation has a TOC value of $4.76 \%$, implying very good productivity of hydrocarbons, i.e., high production ability. Zubair Formation showed a TOC value of $1.91 \%$, which reached to $2.26 \%$, indicating good to very good levels of productivity of hydrocarbons, i.e. high production ability. Yamama Formation had a TOC value of $1.68 \%$, which implies good productivity of hydrocarbons, i.e. high production ability (Figure-2). 
Table-4 demonstrates the geochemical indicators for source rocks efficiency, where (A) represents the production ability (quantity) of immature source rocks and (B) represents the thermal maturity of source rocks [7].

\section{Type of organic matter}

The type of organic matter was determined by two methods: first, the optical method to classify kerogen of organic matters with amorphous structure, using palynological thin sections of Nahr Umr, Zubair and Yamama Formations, which were prepared in the laboratories of the Department of Geology/University of Baghdad. The method was based on that described in a previous article [8] (Plate-1). Second, the pyrolysis method to determine the type of kerogen of source rocks samples from the three Formations was conducted in the laboratories of GeoMark (Table-3).

Figures- $(3,4$, and 5) indicate that the majority of the kerogen were of the types I, II and the mixed type II / III, which produce oil and gas. Most of kerogen type (A) is a producer of oil in a relationship with sedimentary organic matters of amorphous structures [8].

Table 3- Rock-Eval pyrolysis data of the studied samples (GeoMark Laboratories)

\begin{tabular}{|c|c|c|c|c|c|c|c|c|c|c|c|c|c|}
\hline \multirow{2}{*}{$\begin{array}{c}\text { Sample } \\
\text { No. }\end{array}$} & \multirow{2}{*}{$\begin{array}{l}\text { Well } \\
\text { No. }\end{array}$} & \multirow{2}{*}{$\begin{array}{c}\text { Depth } \\
\text { (m) }\end{array}$} & \multirow{2}{*}{$\begin{array}{c}\text { Formatio } \\
\mathbf{n}\end{array}$} & \multirow{2}{*}{$\begin{array}{c}\text { Sample } \\
\text { Type }\end{array}$} & \multirow{2}{*}{$\underset{\%}{\text { TOC }}$} & \multirow{2}{*}{ S1 } & \multirow{2}{*}{ S2 } & \multirow{2}{*}{ S3 } & \multirow{2}{*}{$\begin{array}{c}\begin{array}{c}\text { Tma } \\
\mathbf{x}\end{array} \\
\left(\mathrm{C}^{\mathbf{0}}\right) \\
\end{array}$} & \multirow{2}{*}{$\begin{array}{c}\text { PI } \\
\text { S1/(S1+S2 } \\
\text { ) } \\
\end{array}$} & \multirow{2}{*}{$\begin{array}{c}\text { HI } \\
\text { S2/TOC } \\
(\%)\end{array}$} & \multirow{2}{*}{$\begin{array}{c}\text { OI } \\
\text { S3/TOC } \\
(\%)\end{array}$} & \multirow{2}{*}{$\begin{array}{c}\text { PP } \\
\begin{array}{c}\text { S1+S } \\
2\end{array} \\
\end{array}$} \\
\hline & & & & & & & & & & & & & \\
\hline 1 & Su-14 & 2562 & Nahr Umr & Core & 4.76 & $\begin{array}{l}0 . \\
9\end{array}$ & $\begin{array}{c}23 . \\
1\end{array}$ & $\begin{array}{l}0 . \\
4\end{array}$ & 432 & 0.04 & 485 & 8 & 24 \\
\hline 2 & Su-9 & 2767 & Zubair & Core & 1.91 & $\begin{array}{l}7 . \\
5\end{array}$ & $\begin{array}{c}14 . \\
3\end{array}$ & $\begin{array}{l}0 . \\
3\end{array}$ & 428 & 0.34 & 749 & 16 & 21.8 \\
\hline 3 & Su-9 & 2775 & Zubair & Core & 2.26 & $\begin{array}{l}0 . \\
4\end{array}$ & 4.6 & $\begin{array}{l}0 . \\
6\end{array}$ & 433 & 0.08 & 203 & 27 & 5 \\
\hline 4 & Su-8 & 2785 & Yamama & Core & 1.68 & $\begin{array}{l}6 . \\
3 \\
\end{array}$ & $\begin{array}{c}12 . \\
1\end{array}$ & $\begin{array}{l}0 . \\
3\end{array}$ & 428 & 0.34 & 720 & 18 & 18.4 \\
\hline
\end{tabular}

Table 4- Geochemical indicators of source rocks efficiency; (A) Production efficiency of the source rocks (immature) and (B) Thermal maturation [7]

\begin{tabular}{|c|c|c|c|c|}
\hline Quantity & $\begin{array}{c}\text { TOC } \\
(\mathbf{w t . \%})\end{array}$ & $\begin{array}{c}\text { S 1 } \\
(\mathbf{m g} \text { H C/g rock })\end{array}$ & $\begin{array}{c}\text { S 2 } \\
(\mathbf{m g} \text { H C/g rock })\end{array}$ & $\begin{array}{c}\text { PP } \\
(\mathbf{m g} \text { H C/g rock })\end{array}$ \\
\hline Poor & $0.0-0.5$ & $0.0-0.5$ & $0.0-2.5$ & $0.0-3.0$ \\
\hline Fair & $0.5-1.0$ & $0.5-1.0$ & $2.5-5.0$ & $3.0-6.0$ \\
\hline Good & $1.0-2.0$ & $1.0-2.0$ & $5.0-10.0$ & $6.0-12.0$ \\
\hline Very Good & $>2.0$ & $>2.0$ & $10.0-20.0$ & $12.0-24.0$ \\
\hline
\end{tabular}

(A)

\begin{tabular}{|c|c|c|c|c|c|c|}
\hline \multicolumn{4}{|c|}{ Maturation } & \multicolumn{3}{c|}{ Generation } \\
\hline Maturity & Ro $(\%)$ & Tmax $\left(\mathbf{C}^{\text {o }}\right)$ & TAI & $\begin{array}{c}\text { Bitumen } \\
\text { TOC }(\%)\end{array}$ & $\begin{array}{c}\text { Bitumen } \\
(\mathbf{m g} / \text { g rock) }\end{array}$ & $\begin{array}{c}\text { PI } \\
(\mathbf{m g} \text { HC/g rock) }\end{array}$ \\
\hline Immature & $0.20-0.60$ & $<435$ & $1.5-2.6$ & $<0.05$ & $<50$ & $<0.10$ \\
\hline (Early) Mature & $0.60-0.65$ & $435-445$ & $2.6-2.7$ & $0.05-0.10$ & $50-100$ & $0.10-0.15$ \\
\hline (Peak) Mature & $0.65-0.90$ & $445-450$ & $2.6-2.7$ & $0.15-0.25$ & $150-250$ & $0.25-0.40$ \\
\hline$($ Late) Mature & $0.90-1.35$ & $450-470$ & $2.9-3.3$ & - & - & $>0.40$ \\
\hline$($ Post) Mature & $>1.35$ & $>470$ & $>3.3$ & - & - & - \\
\hline
\end{tabular}

(B) 


\section{Organic thermal maturity}

\section{Optical measurement of organic maturity}

The optical techniques are mostly used recently in determining source rock maturity [9], through evaluating the relationship between the color of the spore textures and degree of change. They describe the color of the light transmitted in the microscopic organic molecule, where they need accuracy and apply many scales [5, 10-12] (Figure-7).

\section{Chemical techniques to measure thermal maturity}

This approach is represented by the pyrolysis technique. The optical methods and the pyrolysis analysis were used in the present study by measuring the maximum temperature (Tmax) and its applications as an indicator of maturity (Table-3).

It is clear from the results of Figures-(4 and 6) that Nahr Umr Formation is immature, while the maturity of Zubair and Yamama Formations is thermally low.

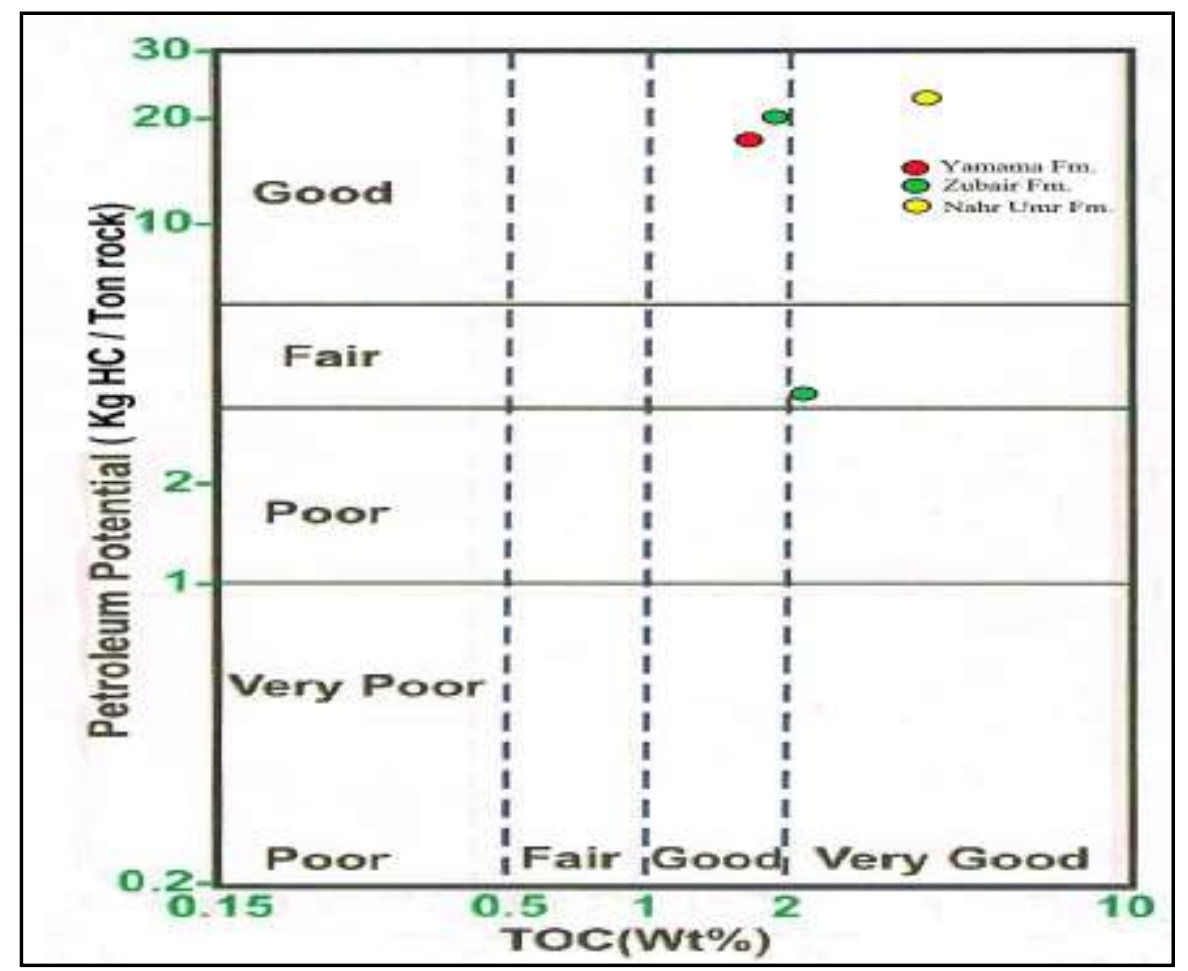

Figure 2- Petroleum efficiency for source rocks in the study area [13].

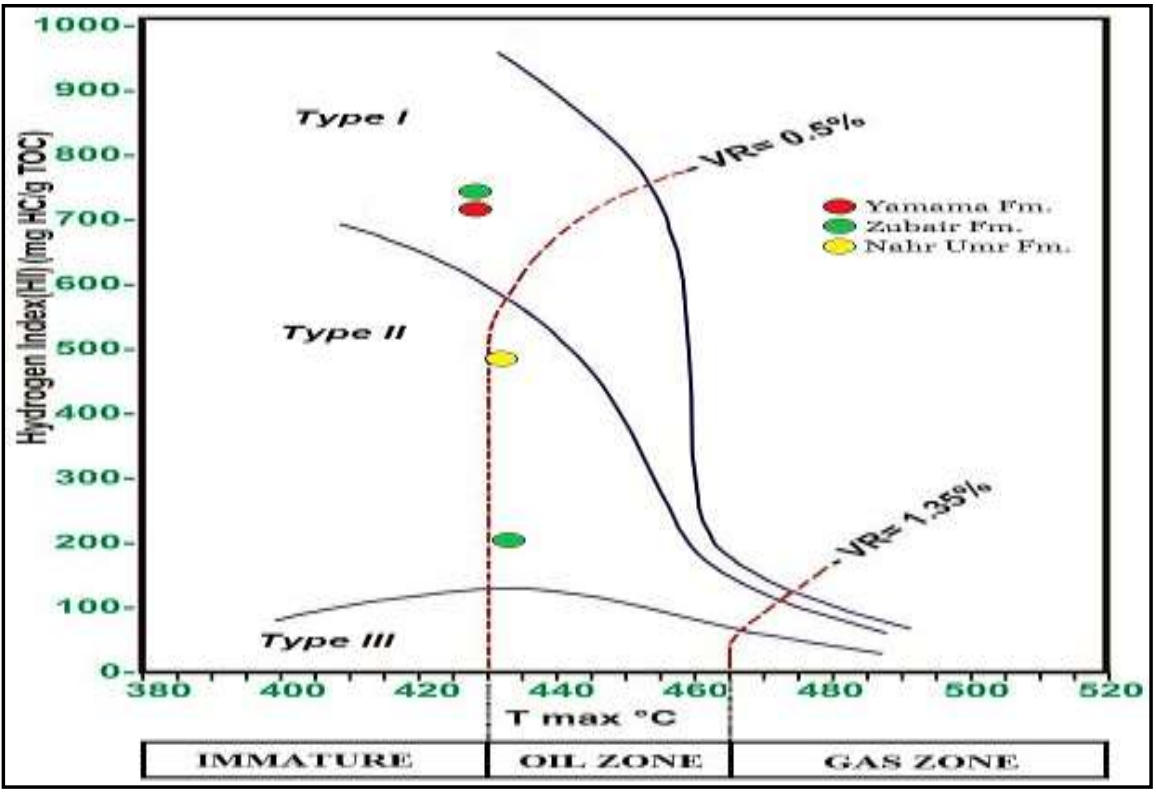

Figure 3- Determination of kerogen type for source rocks in study area [13]. 


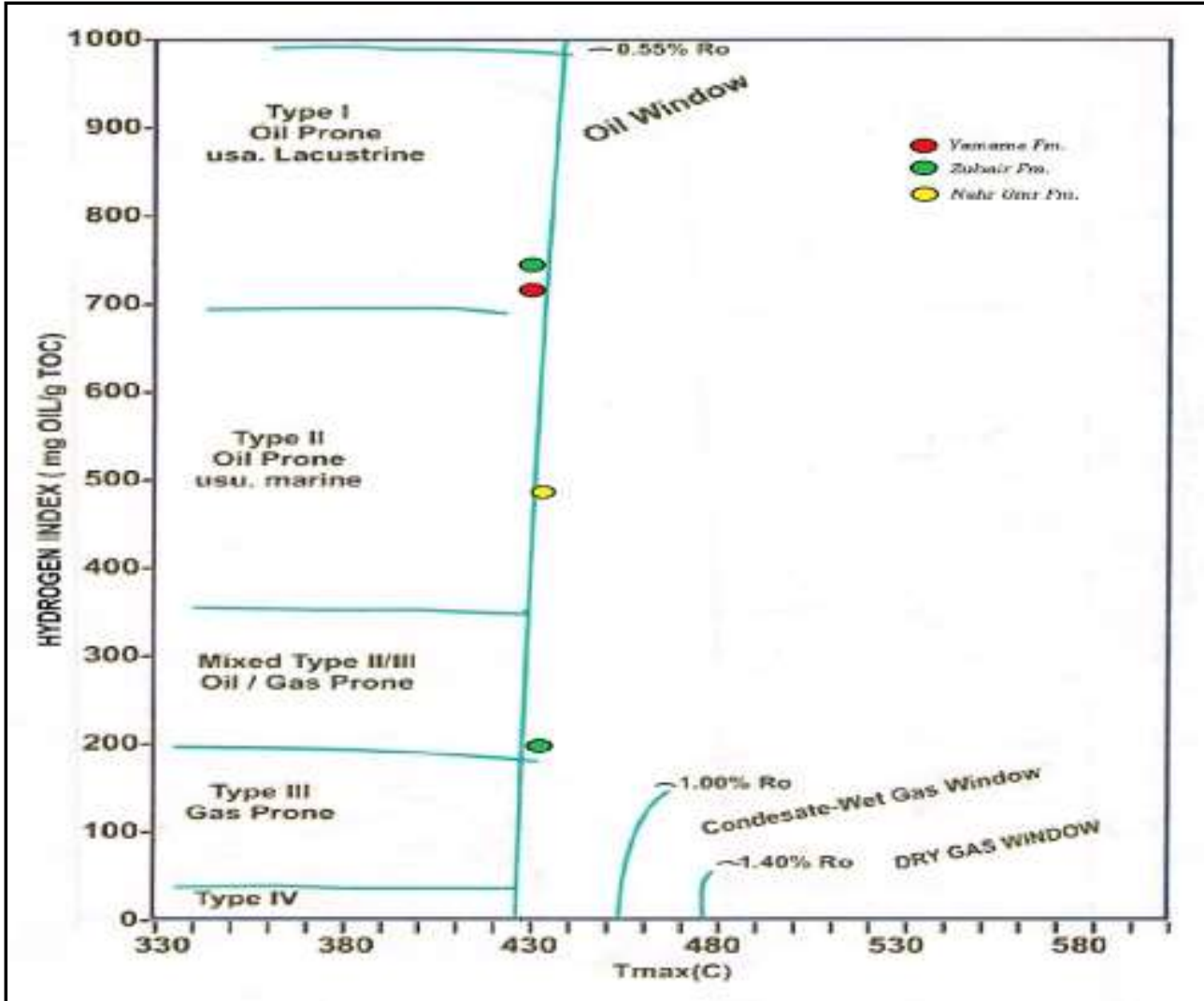

Figure 4- Type of kerogen and maturation depending on Tmax values (GeoMark Research Inc., Houston).

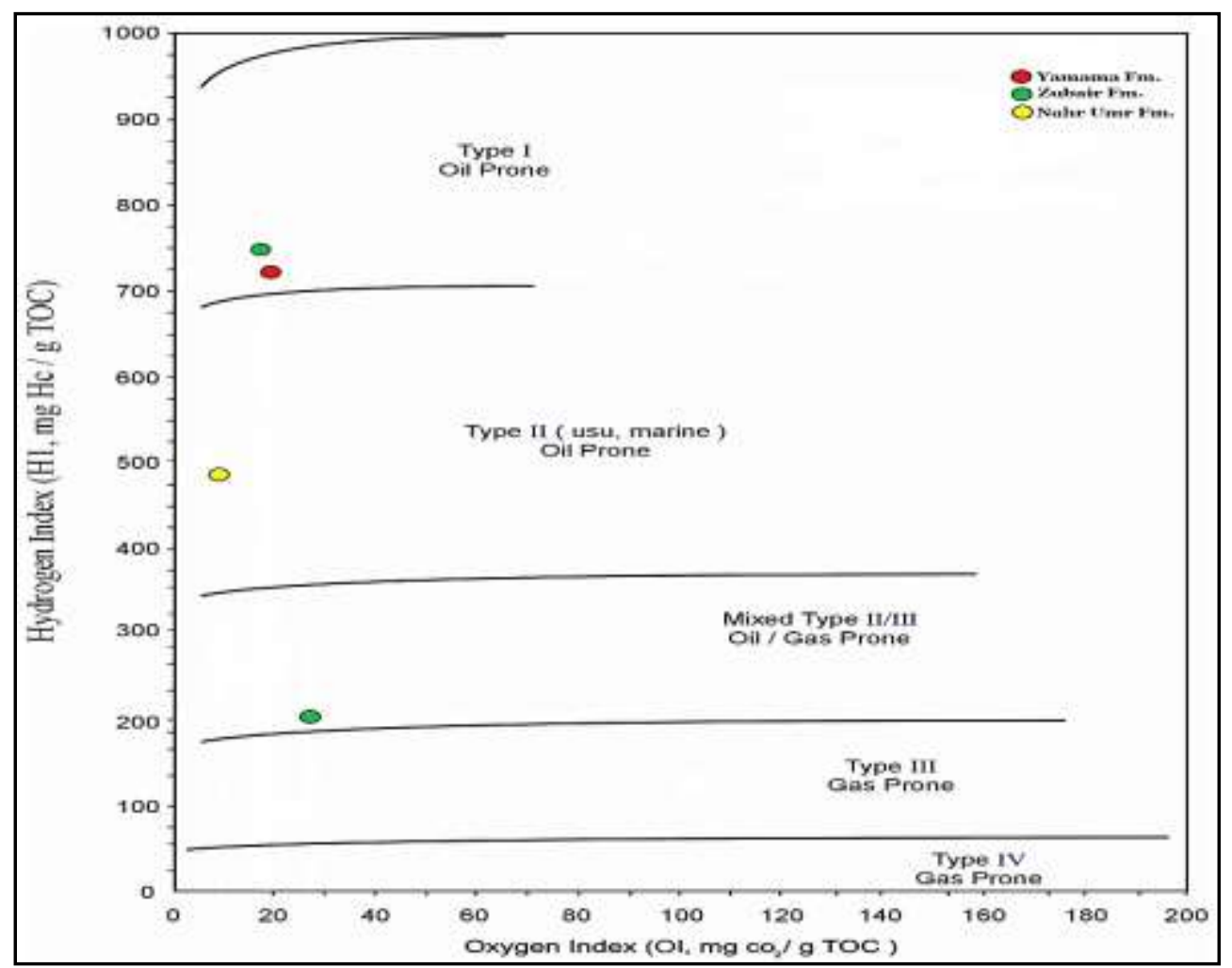

Figure 5- Determination of kerogen type from relation between Hydrogen Index and Oxygen Index (GeoMark Research Inc., Houston). 


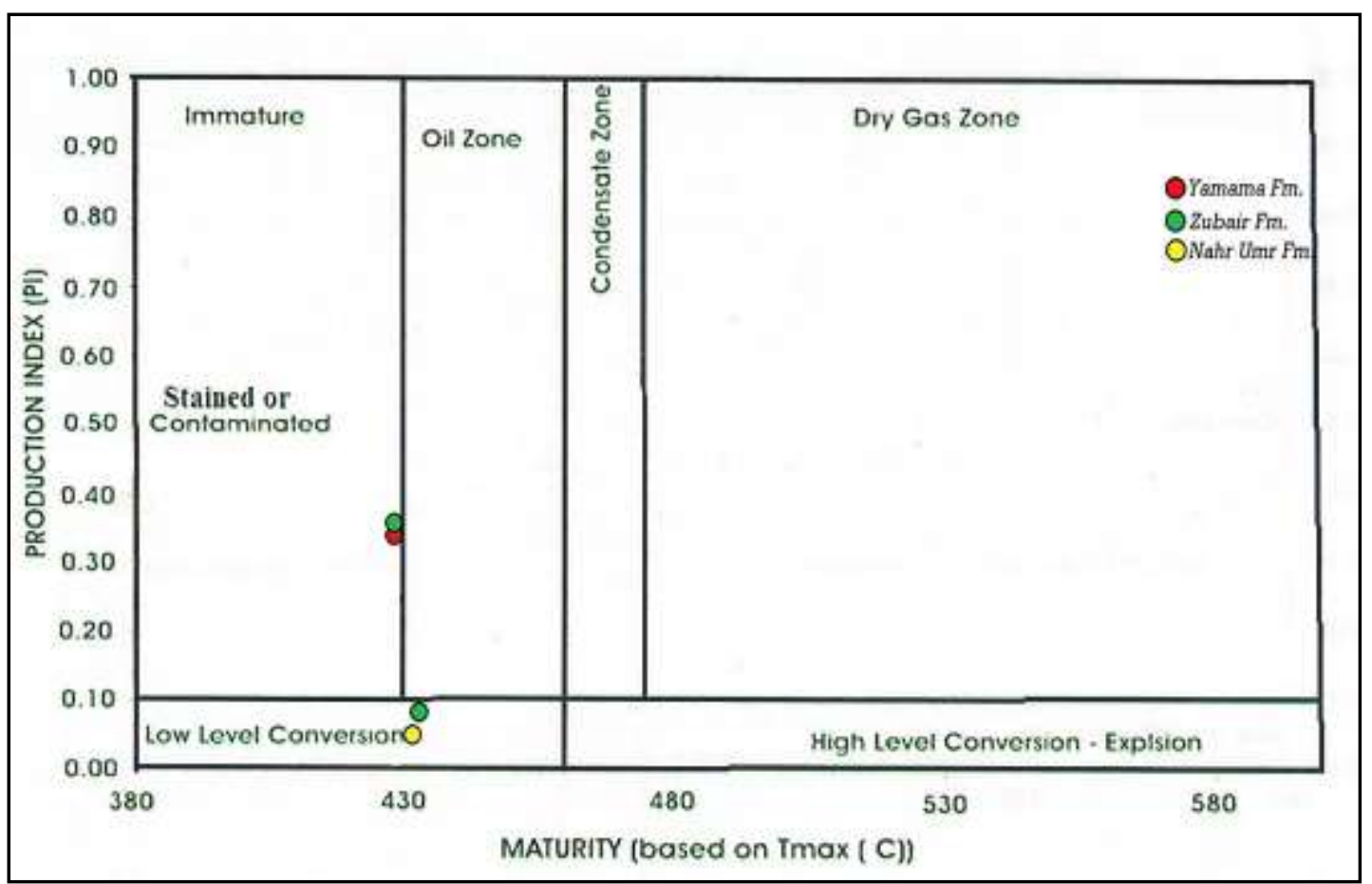

Figure 6- Change of kerogen and thermal maturity depending on Tmax values (sheet of GeoMark Research Inc., Houston).

\begin{tabular}{|c|c|c|c|c|c|c|c|}
\hline \multicolumn{2}{|r|}{ TAI } & \multirow[b]{2}{*}{$\mathrm{VR}$, } & \multicolumn{2}{|r|}{ Fluorescence } & \multirow{2}{*}{$\begin{array}{l}\text { Organic } \\
\text { maturity }\end{array}$} & \multirow{2}{*}{${ }_{{ }^{\circ} \mathrm{C}}^{\text {Temp. }}$} & \multirow[b]{2}{*}{ Hydrocarboa generation } \\
\hline scale & Pollen color & & $\lambda \max$. & Pollen color & & & \\
\hline 1 & $\begin{array}{l}\text { Colorless to Light } \\
\text { Yellow }\end{array}$ & 0.2 & 570 & $\begin{array}{l}\text { Green to yellowish } \\
\text { green. }\end{array}$ & \multirow{3}{*}{ Immature } & 25 & \\
\hline$I^{\prime}$ & Light Yellow & 0.3 & & Yellow & & 32 & $\begin{array}{l}\text { Biogenic methan (march gas-early } \\
\text { diagenetic methan) }\end{array}$ \\
\hline 2 & Yellow & 0.38 & & Yellow -Orange & & 50 & \\
\hline 2 & Organic Yellow & 0.45 & 580 & Light orange & \multirow[b]{3}{*}{ Mature } & 65 & first oil formation (oil 'birth ' zone ) \\
\hline 2 & Dark Yellow & 0.61 & & Moderate orange & & 90 & Peak oil generation \\
\hline 3 & $\begin{array}{l}\text { Light Yellowish } \\
\text { brown }\end{array}$ & 0.78 & 590 & Dark orange & & 120 & Main phase of oil expulsion \\
\hline 3 & Light brown & 0.98 & & Orange-Red & & 150 & Peak condensate and wet-gas generation \\
\hline $3^{+}$ & Broma & 1.16 & & Red & & 200 & $\begin{array}{l}\text { Peak dry gas generation (thermoganic } \\
\text { methan) }\end{array}$ \\
\hline 4 & Dark Brown & 1.71 & 660 & No Fluorescence & Post-Mature & 220 & Oil floor (oil "death"zone) \\
\hline 4 & Brownish black & 258 & & & & 250 & Condensate and wet-gas floor \\
\hline 5 & Black \& deformed & 8.30 & & & & 320 & Dry gas preservation limit \\
\hline
\end{tabular}

Figure 7- Diagram to determine thermal maturation for organic sedimentary materials, after [10-12].

\section{Source Rocks Evaluation}

\section{Nahr Umr Formation}

\section{Total organic carbon (TOC)}

The TOC value was $4.76 \%$ at a depth of $2562 \mathrm{~m}$ in well Su-14 of Nahr Umr Formation (Table-3), which is considered very good in relation to the generation of hydrocarbons, depending on the published classification [7] (Table-4 and Figure-2). In general, the lower parts of the well are rich in sedimentary organic matter, which reached nearly $5 \%$. 


\section{Type of organic matter}

Organic materials with amorphous structure type (A) were dominant in Nahr Umr Formation, while they also represent the kerogen type (II) oil prone (Figures-3, 4 and 5, Plates-1 and 2).

Thermal Maturity

The results showed that the source rocks of Nahr Umr Formation are considered immature with a Tmax value of $432 \mathrm{C}^{\circ}$ Table-3, Figures-(4 and 6).

\section{Zubair Formation}

\section{Total organic carbon (TOC)}

The values of organic matter in Zubair Formation samples (Su-9) were ranging between $1.91 \%$ in the depth of $2767 \mathrm{~m}$ and $2.26 \%$ in the depth of $2775 \mathrm{~m}$ (Table-3).

TOC levels for Zubair Formation are considered good to very good in relationship to the generation of hydrocarbons, depending on the previously described classification [7] (Table-4) and (Figure-2).

\section{Type of organic matter}

Types of kerogen which are prevalent in this Formation depending on the classification of Tissot and Welte (1984) are I \& II/III, whereas according to another type of classification [8] the organic materials were amorphous organic matters (AOM) of the types A\&D (Table-3), Figures-(3, 4, and 5), Plates-1 and 2).

\section{Thermal Maturity}

The Formation is considered as having low thermal maturity with the value of $\operatorname{Tmax}=428,433 \mathrm{C}^{\circ}$ (Table-3), Figures-(4 and 6).

\section{Yamama Formation}

\section{Total organic carbon (TOC)}

The organic material value was $1.68 \%$ at the depth of $3585 \mathrm{~m}$ in well Su-8 (Table-3). The total organic carbon for Yamama Formation is considered as good in relation with the generation of hydrocarbons, (Table-4 and Figure-2).

\section{Type of organic matter}

Organic materials with amorphous structure type (A) were dominant in this Formation, while they also represent the kerogen type (I) of a very good oil (Figures-3, 4 and 5, Plates-1 and 2).

\section{Thermal Maturity}

The studied source rocks are considered as having low thermal maturity with Tmax value of $428 \mathrm{C}^{\circ}$ (Table-3, Figures-4 and 6).

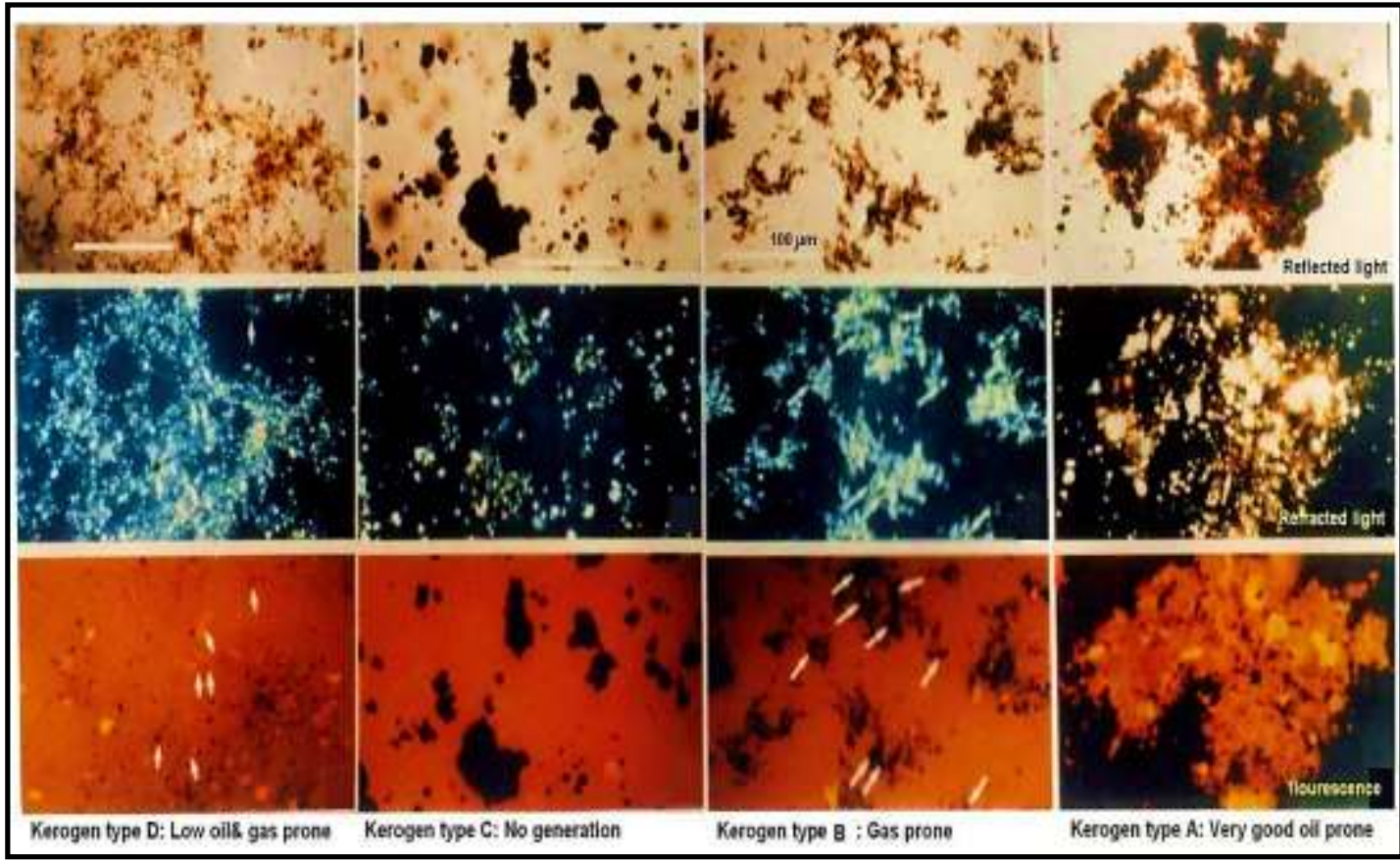

Plate 1- Microscopic description to kerogen with amorphous structures [8]. 


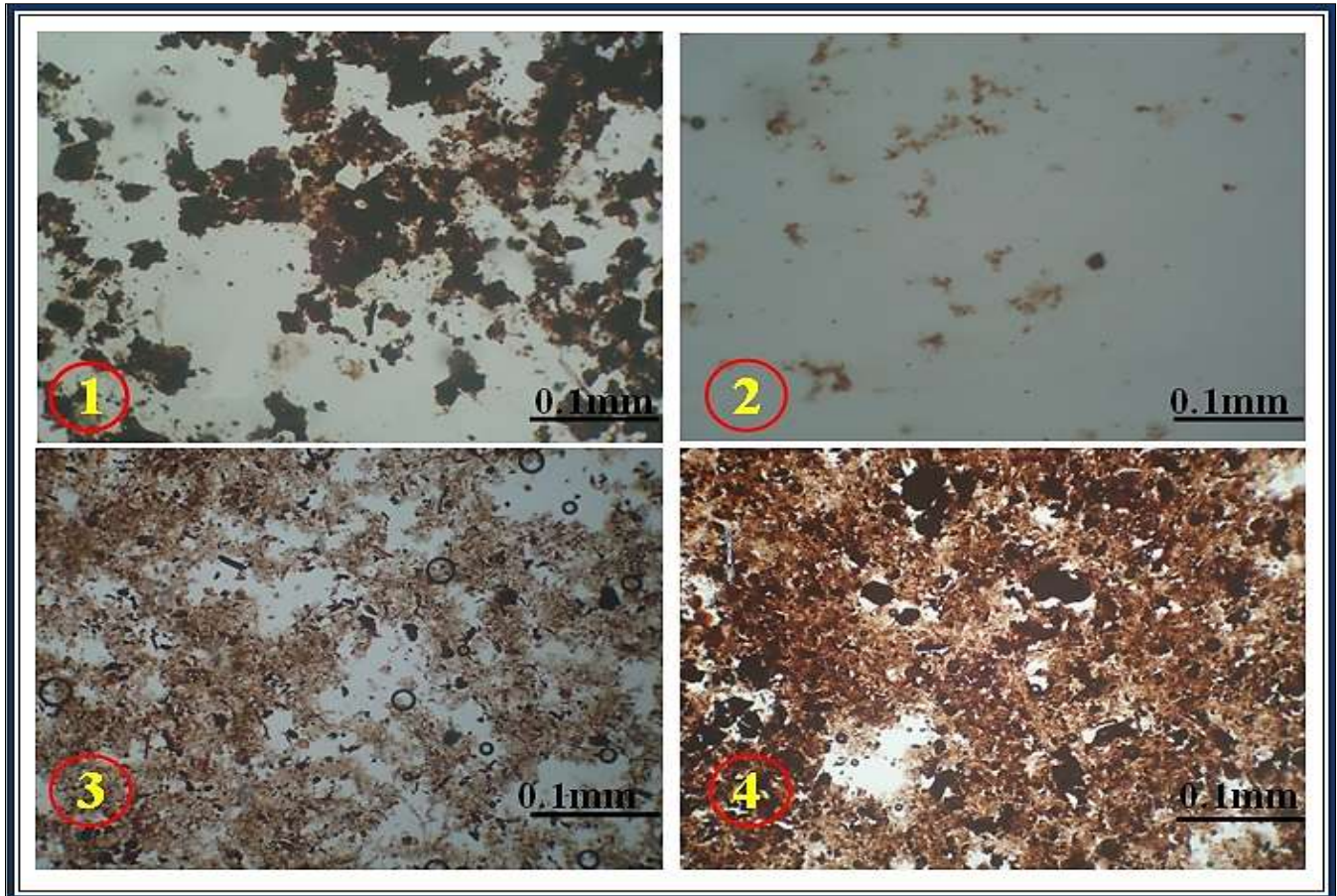

Plate 2- Selected microscopic views of amorphous organic matters from Nahr Umr, Zubair and Yamama Formations. 1) Kerogen type (A) of the Yamama Formation, well Su-8, depth 3585 m. 2) Kerogen type (D) of, Zubair Formation, well Su-9, depth 2767 m. 3) Kerogen type (A) of, Zubair Formation, well Su-9, depth 2775 m. 4) Kerogen type (A) of the Nahr Umr Formation, well Su-14, depth $2562 \mathrm{~m}$.

\section{Palynofacies Analysis}

To assess the palaeoenvironment and the potentiality to generate hydrocarbons, facies analysis was performed by microscopic test. The results were compared with those of the organic geochemical analyses, which were performed in the American GeoMark Research Inc. to differentiate the various palynological sedimentary facies. Many palynological materials, including spores, dinoflagellate, and amorphous organic matters were diagnosed.

To determine the environmental location for each palynofacies, the microscopic test results are represented as percentage ratio, and then values were projected on diagrams of triangles based on a previous work [5]. The importance of these diagrams comes from their ability to determine the environments of the locations in addition to the detailed environment explanations, e.g., paleoclimate conclusions and changes in the marine surface level, as well as the potentiality to generate hydrocarbons.

\section{Palynofacies}

Palynofacies is a group of organic microfossils, which resist dissolution in organic solvents and anoxic acids and have a limited geographic extent. There are many variables and factors, which affect their distribution as palynological organic sediments [5]. The determination of the facies helps in the interpretation of sedimentary palaeoenvironment, paleoclimate and the changes in marine surface levels [14], as well as the maturation level to determine the hydrocarbon potential.

Many sedimentary organic matters, which include dinoflagellate, spores and foraminiferal matter, were identified in this study, in addition to amorphous organic matters. This study depends on the facies classification used by a previous study [5] in a form of APP (Amorphous-PhytoclastPalynomorph) triangle. Accordingly, palynofacies are determined by facies classifications of the sedimentary organic matters to determine depositional environment, and kind of organic matter from the knowledge of palynological components. The classification of these facies [5] according to the present results is as follows. First, Palynofacies VIII- Distal dysoxic-oxic shelf, which is characterized by the domination of amorphous organic matter assemblages with an excellent preservation and low to moderate palynomorphs (partly due to masking). These are typical of organic-rich shales deposited under stratified shelf sea conditions, with low to moderate Dinocysts and spores and pollens along 
with the dominance of \%prasinophytes increasing. Second, Palynofacies IX- Distal suboxic-anoxic basin, characterized by the dominance of amorphous organic matter assemblages and low abundance of palynomorphs partly due to masking, frequently alginite-rich. It also has deep basin or stratified shelf sea deposits, especially sediment starved basins, where spores, pollens and microplanktons are generally of low proportion and prasionphytes are often dominant.

Table-5 represents the percentages of the three groups (Amorphous, Phytoclast, and Palynomorph). Depending on the percentages of the three groups in addition to the geochemical organic analyses, two main palynofacies were distinguished in the wells of study area.

The followings are the main characters of these facies. First, Palynofacies (PF1); this facies was included within carbonate rocks of the Yamama Formation and part of Zubair Formation. It appeared at depths of $3585 \mathrm{~m}, 3622 \mathrm{~m}$ and $3669 \mathrm{~m}$ in the well Su-8, and at a depth of $2767 \mathrm{~m}$ in the well Su-9.

This facies was characterized by the dominance of AOM with a percentage reaching $99 \%$, whereas the phytoclasts represented a low percentage of 5\% and the palynomorphs was absent (Plates-2, 3A and 3B).

This facies was also characterized by a good content of TOC, reaching $1.68 \%$ in the Yamama Formation and $1.91 \%$ in the Zubair Formation. The kerogen types (A) and (D) were dominant in the Yamama and Zubair Formations, respectively, which tend to produce hydrocarbons. Also the dominant kerogens of type (I) and (II/III) were present in the Yamama and Zubair Formations, respectively, according to the other classification adopted by the present study.

Second Palynofacies (PF2); this facies was located within the sandstone, interbedded within the shale, and the siltstone of Nahr Umr and part of Zubair Formations. It appeared at the depths of $2562 \mathrm{~m}$ in the well Su-14 and 2775m, 2780.5m and 2784.5m in the well Su-9.

This facies was also characterized by the dominance of AOM, reaching $85 \%$, whereas the phytoclasts formed about $15 \%$. Besides, the palynomorphs such as, spores, pollen, dinoflagellate, and other palynomorphs, represented $18 \%$ (Plates-4A-4C and 5).

The levels of TOC in Nahr Umr and Zubair Formations are considered very good to produce hydrocarbons, reaching $4.76 \%$ and $2.26 \%$, respectively. In addition, the results showed that the kerogen was of type (A) of the amorphous organic matter in Nahr Umr and Zubair formations, which tends to generate liquid hydrocarbons. According to the third type of classification, the dominant kerogen was of type (II) and type (I) were present in the Nahr Umr Formation and Zubair Formations, respectively,

Table 5- Percentages of kinds of organic matter groups.

\begin{tabular}{|c|c|c|c|c|c|c|}
\hline $\begin{array}{c}\text { Sample } \\
\text { No. }\end{array}$ & Well No. & Formation & Depth (m) & $\begin{array}{c}\text { Palynomorph } \\
\text { \% }\end{array}$ & Phytoclast \% & AOM\% \\
\hline 1 & Su-14 & Nahr Umr & 2562 & 8 & 7 & 85 \\
\hline 2 & Su-9 & Zubair & 2767 & 0 & 0 & 100 \\
\hline 3 & Su-9 & Zubair & 2775 & 10 & 15 & 75 \\
\hline 4 & Su-9 & Zubair & 2780.5 & 18 & 10 & 72 \\
\hline 5 & Su-9 & Zubair & 2784.5 & 10 & 12 & 78 \\
\hline 6 & Su-8 & Yamama & 3585 & 0 & 1 & 99 \\
\hline 7 & Su-8 & Yamama & 3622 & 1 & 2 & 97 \\
\hline 8 & Su-8 & Yamama & 3669 & 0 & 5 & 95 \\
\hline
\end{tabular}




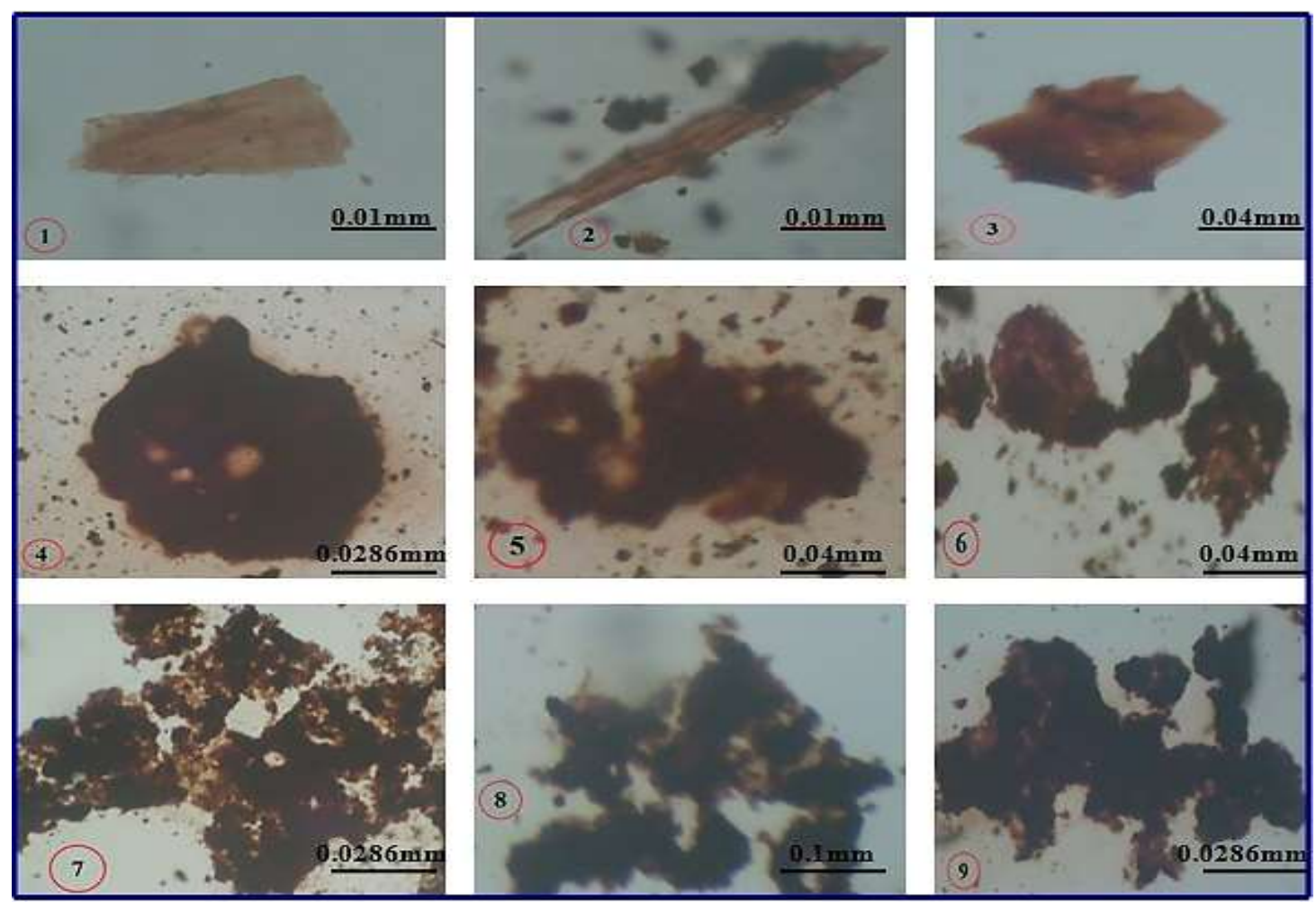

Plate 3A- Sedimentary Organic Matters of Yamama Formation, well Su-8, depth 3585m. 1-3) Tracheid (phytoclast). 4) Degraded phytoclast. 5-9) Amorphous organic matters of kerogen type (A).

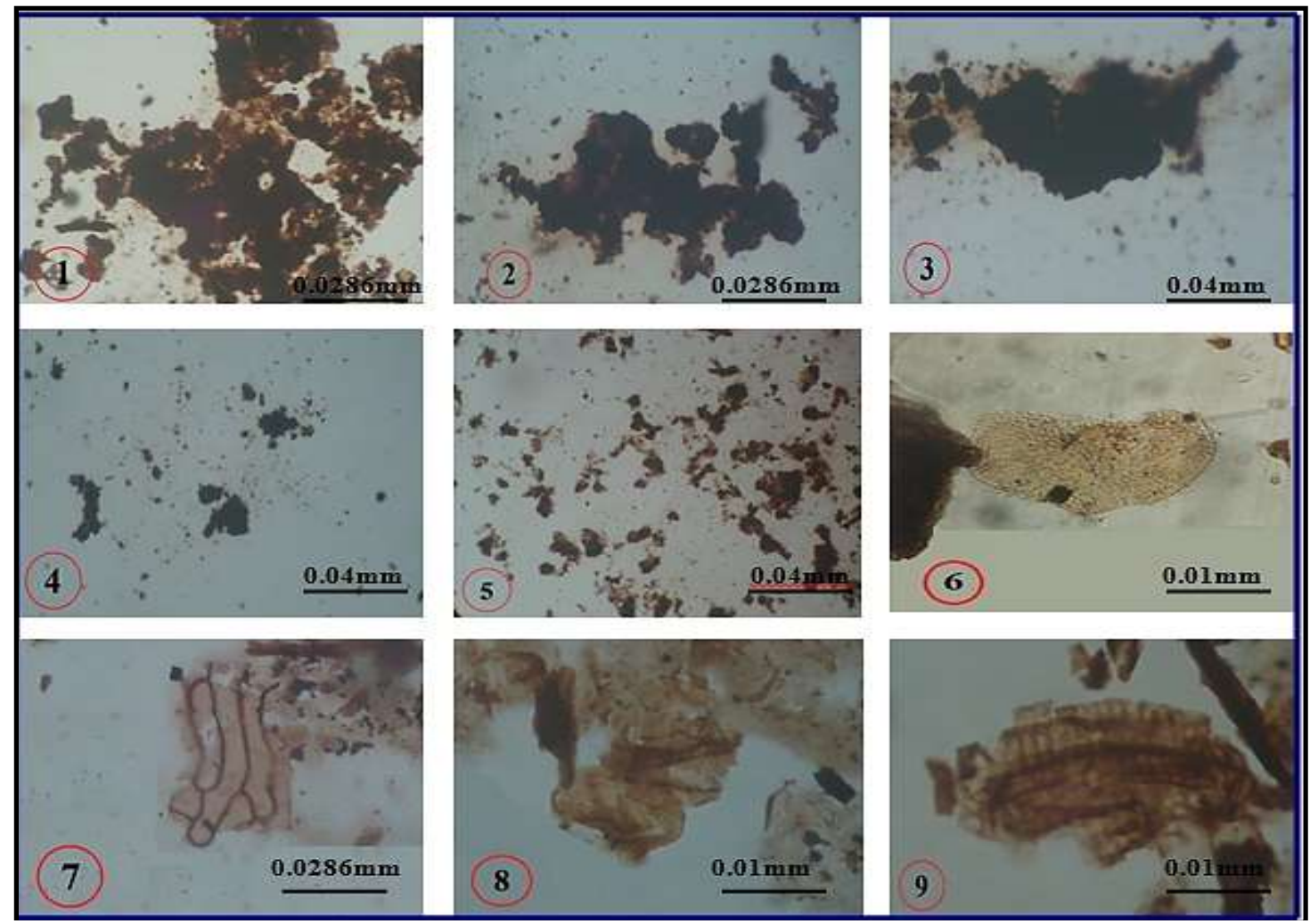

Plate 3B- Sedimentary Organic Matters of Yamama Formation, well Su-8, depths 3622m and 3669m. 1-5. Amorphous organic matters of kerogen type (A), from depths $3622 \mathrm{~m}$ and $3669 \mathrm{~m}$., respectively. 6. Cleistosphaeridium aciculare Davey 1969, depth $3622 \mathrm{~m}$. 7\&9. Phytoclast of Cuticle, depths $3622 \mathrm{~m}$ and $3669 \mathrm{~m}$. 8. Tracheid (phytoclast), depth 3669m. 


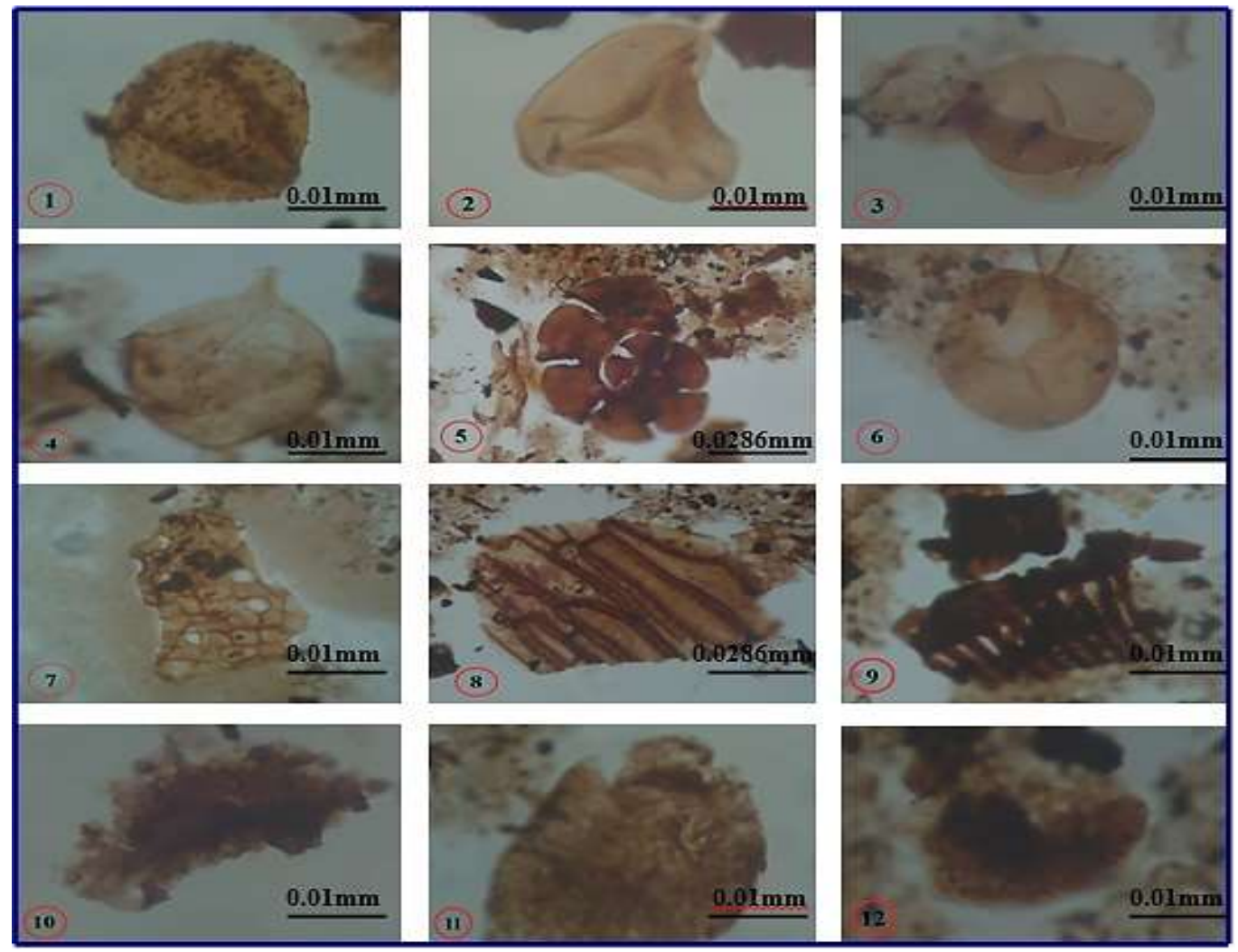

Plate 4A- Sedimentary Organic Matters of Zubair Formation, well Su-9, depth 2775m. 1. Verrucosisporites sp. 2-3\&6. Cyathidites australis. 4. Subtilisphaera perlucida (Dinoflagellate). 5. Foraminiferal test lining. 7-9. Phytoclast of Cuticle \& Tracheid. 10. Amorphous organic matters of kerogen type (A). 11-12. Degraded organic matters.

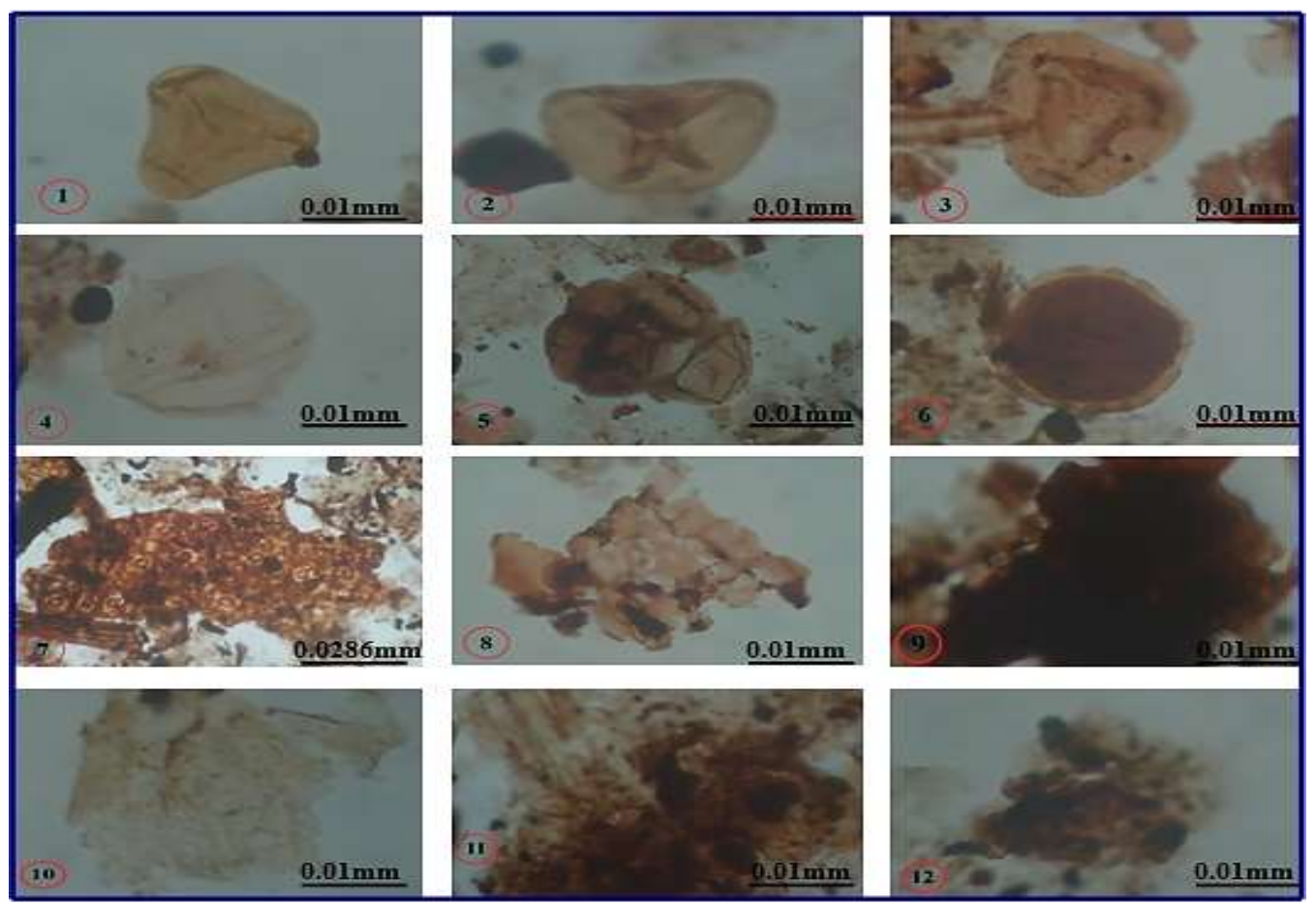

Plate 4B- Sedimentary Organic Matters of Zubair Formation, well Su-9, depth 2775m. 1-2. Concavisporites jurienensis. 3. Concavissimisporites variverrucatus. 4. Subtilisphaera perlucida. 5. Foraminiferal test lining. 6. Aequitriradites spinulosus. 7-8. Phytoclast of Cuticle. 9. Resin (plant segression). 10-12. Amorphous organic matters. 


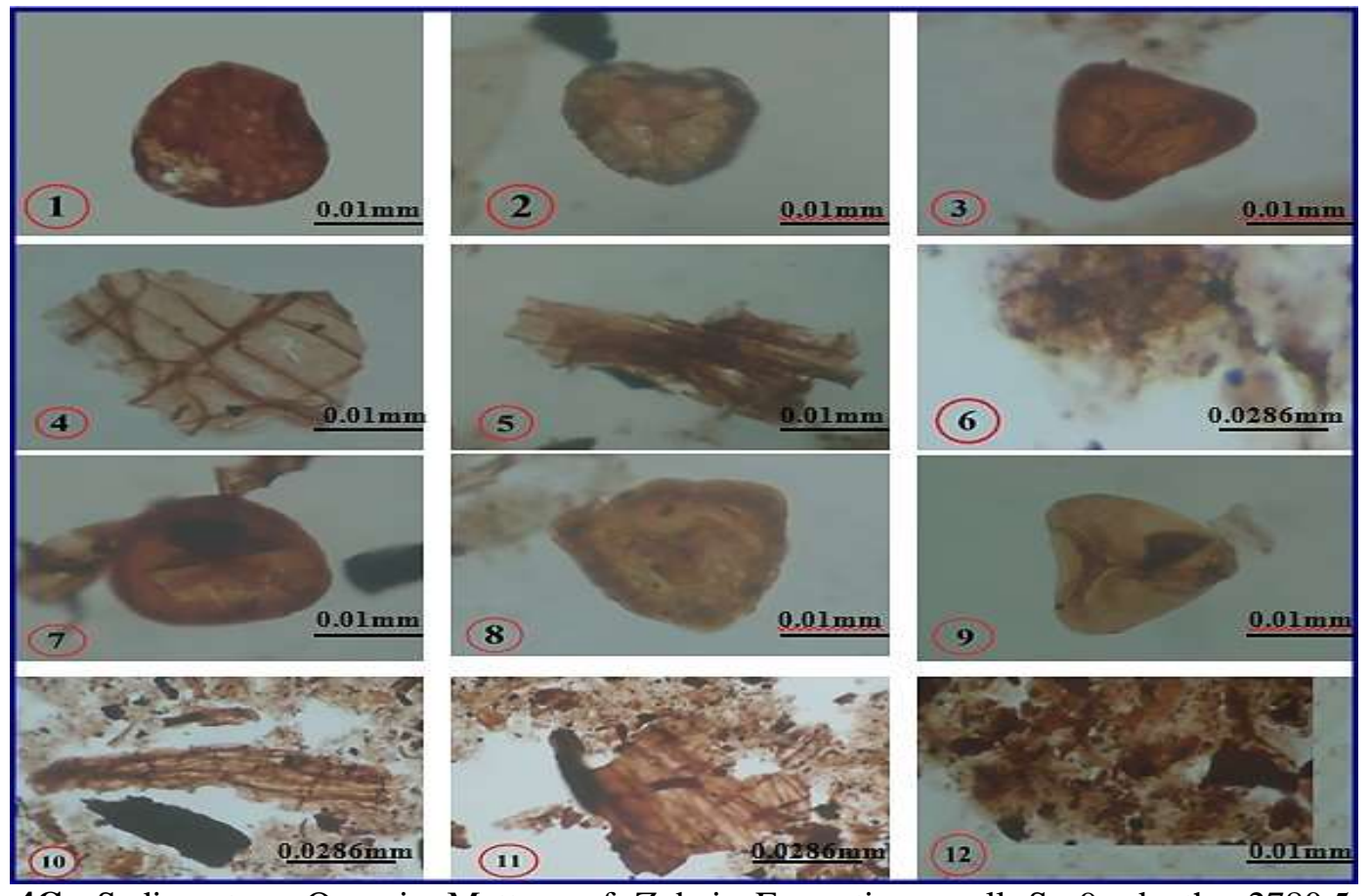

Plate 4C- Sedimentary Organic Matters of Zubair Formation, well Su-9, depths $2780.5 \mathrm{~m}$ and 2784.5m. 1. Lycopodiumsporite austroiclavatidites (Cookson) Potonie 1976, depth 2780.5m. $2 \& 9$. Gleichenidites senonicus Ross 1949 , depths $2780.5 \mathrm{~m}$ and $2784.5 \mathrm{~m}$. 3. Trilobosporites ivanova Batten 1973 , depth $2780.5 \mathrm{~m} \mathrm{4}$, 10\&11. Cuticle of vascular land plants, depths $2780.5 \mathrm{~m}$ and $2784.5 \mathrm{~m}$. 5 . Trachied of vascular land plants, depth $2780.5 \mathrm{~m} .6 \& 12$. Amorphous organic matters of kerogen type (A), depths 2780.5m and 2784.5m 7. Murospora florida (Balme) Potonie 1961, depth 2784.5m. 8. Asbeckiasporites borysphenicus (Voronova) Thedorova - Shakmundes 1976, depth 2784.5m.

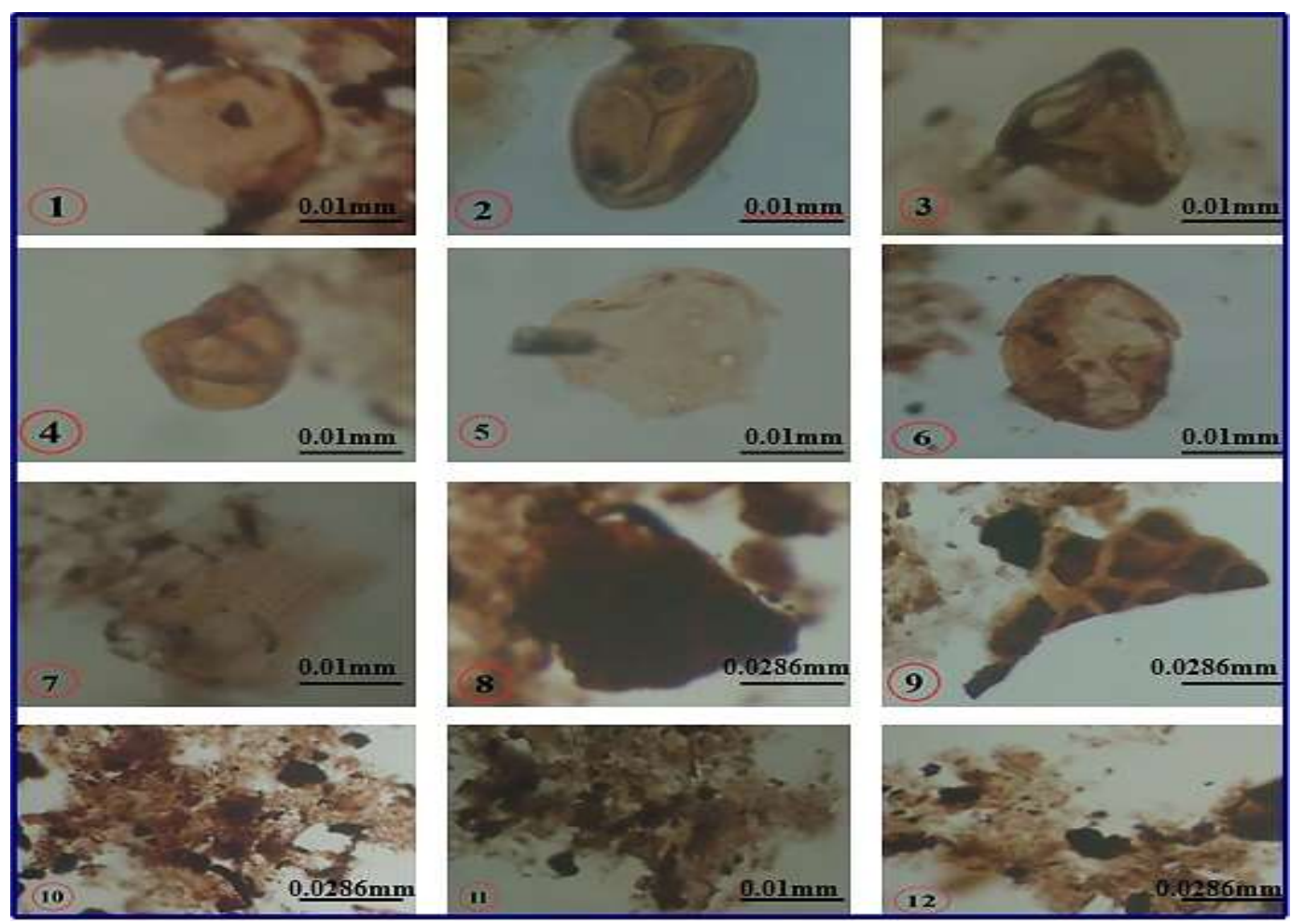

Plate 5- Sedimentary Organic Matters of Nahr Umr Formation, well Su-14, depth 2562m. 1, 5 \& 6. Thomsonipollis mangnificus. 2-3. Cyathidites australis. 4. Phytoclast. 7. Degraded dinocyst. 8. Resin (plant segression). 9. Cuticle. 10-12. Amorphous organic matters of kerogen type (A). 


\section{Sedimentary paleoenvironment}

It could be conclude from the previous presentation of the palynofacies that the main contents were spores, pollens, dinocysts and amorphous organic matters. Based on the statistical operations between these contents, the sedimentary paleoenvironment was diagnosed according to the percentages of organic matters of the triangle APP described previously [5]. Two facies were diagnosed from the sedimentary paleoenvironment, as described in the following. First, the Paleoenvironment of Nahr Umr Formation; palynofacies (VIII) distal dysoxic-oxic shelf is correlated with the second palynofacies (PF2). This palynofacies is characterized by the dominance and abundance of wellpreserved AOM, with low abundance of palynomorphs, partly due to masking, and low phytoclast. They are formed in the marine stratified water, as shown in Figure-8. Second, the Paleoenvironment of Zubair Formation; by projection of analyzed samples on APP triangle, palynofacies (IX) distal suboxic-anoxic basin is correlated with the first palynofacies (PF1), This facies is characterized by dominance and abundance of AOM and low abundance of palynomorphs, partly due to masking, along with offshore facies in which stratified water is dominant, due to the abundance of AOMs [5]. Palynofacies (VIII) distal dysoxic-oxic shelf is correlated with the second palynofacies (PF2), this palynofacies is characterized by the dominance and abundance of well-preserved AOM, with low abundance of palynomorphs, partly due to masking, and low phytoclast. They are formed in marine stratified water, as shown in (Figure-8). Third, Paleoenvironment of Yamama Formation; A distal suboxic-anoxic basin palynofacies. By the projection of the analyzed sample on APP triangle, we notice that they are located within a deep zone of the shelf environment, where these sediments are slowly deposited in a quiet water, i.e., in marine environment far from the coast, and characterized by a good organic matter preservation. The first palynofacies (PF1) is correlated with palynofacies (IX) of one of our adopted classifications [5].

This facies is characterized by dominance and abundance of AOM, low abundance of palynomorphs, partly due to masking, and offshore facies in which stratified water is dominant due to the abundance of AOMs [5]. The cases of stratified water are the reason for the organic production increase, with their larger preservation rocks of Yamama Formation, as indicated in Figure-8.

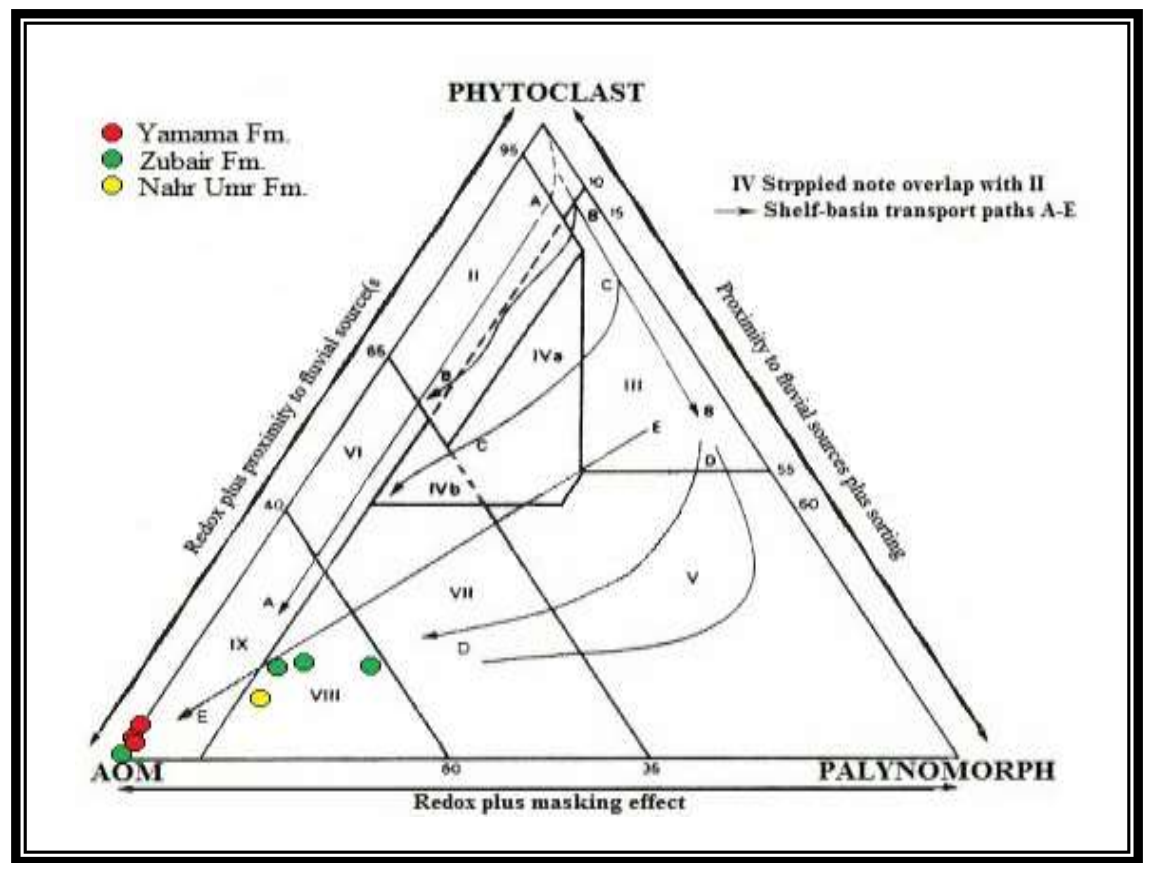

Figure 8- The palynofacies in wells $\mathrm{Su}-14, \mathrm{Su}-9$ and $\mathrm{Su}-8$ according to a previously described classification [5].

\section{Phase of Hydrocarbon Generation and Expulsion}

The interpretation of this stage depends on the indications gathered from geochemical and palynological analyses for kerogen from the three Formations. To refer to facies which have the contents of hydrocarbon generation phase, we studies the paleoenvironment using the triangle APP [5]. 
This approach depends on the percentage of phytoclast, palynomorph and amorphous organic matters and the ability of these rocks to preserve organic matters. It also depends on how these materials are affected by biodegradation and the amount and type of organic matter in the analyzed samples, where the amorphous organic matter type (A) is responsible for oil generation according to previous studies $[8,15]$. The type of kerogen, along with S2 and PP values, lead to the interpretation of oil generation ability of source rocks mentioned above. It is important to refer to thermal maturation, since the source rocks should undergo thermal maturation to be considered as oil generating rocks.

\section{Phase of Hydrocarbon Generation and Expulsion of Nahr Umr Formation}

This formation is located within the second palynofacies (PF2) in distal dysoxic-oxic shelf within a marine environment.

Organic matter values of type (A) of amorphous organic content increase the production of oil [8]. Kerogen from type (II) has a very good TOC content of about 4.76\% [13]. The Formation is considered as having very good content of TOC with high petroleum potential $(\mathrm{PP}=24)$ value at the depth of $2562 \mathrm{~m}$ in well Su-14. Notice that the value of S2 for Nahr Umr Formation at the depth of $2562 \mathrm{~m}$. in well Su-14 was 23.1.

The hydrogen index (HI) value of the depth $2562 \mathrm{~m}$ of well Su-14 is 485 , whereas the production index (PI) value was 0.04 . The rocks of the Formation are considered as having a poor thermal maturation, where the value of Tmax was $432 \mathrm{C}^{\circ}$.

Generally, the Formation has a very good content of sedimentary organic matter, i.e., a type II kerogen Formation, which is not suitable to produce oil hydrocarbons because of thermal immaturity Figures(2-6).

\section{Phase of Hydrocarbon Generation and Expulsion of Zubair Formation}

Rocks of this formation are located within the first palynofacies (PF1) in the distal suboxic-anoxic basin and the second palynofacies (PF2) which reflects the distal dysoxic-oxic shelf within a marine environment.

The Formation is considered as having good to very good content of the TOC and high oil potentiality, with PP values of 21.8 and 5 at the depths of $2767 \mathrm{~m}$ and $2775 \mathrm{~m}$, respectively, in well Su9 .

Organic matter values from types $A \& D$ of amorphous organic content were increased in the Formation, which is able to produce oil [8]. In addition, kerogen types (I and II/III) were observed which have good to very good TOC content of about 1.91-2.26\%.

The measured S2 represents the amount of free hydrocarbon that originates because of thermal cracking of kerogen. S2 values at the depth of $2767 \mathrm{~m}$ and $2775 \mathrm{~m}$ of in well Su-9 were 14.3 and 4.6, while the PI values were 0.35 and 0.08 , respectively, and Tmax values ranged between $428-433 \mathrm{C}^{\circ}$.

In general, the Formation had high to very high organic content, low thermal maturation, and types (I) and (II/III) of kerogen, which implies that it could generate liquid hydrocarbons Figures-(2-6).

\section{Phase of Hydrocarbon Generation and Expulsion of Yamama Formation}

The formation is located within the first palynofacies (PF1) in the distal suboxic-anoxic basin within the deep zone of the shelf environment. The sedimentary organic matter is amorphous (99\%) due to degradation caused by bacteria and its distal marine environment (offshore).

The organic matter is well preserved because it is far from water circulation, which may cause the oxidation of organic matter with the presence of bacterial activity in the previously mentioned facies. This made the percentage of AOM very high with a good TOC value. The kerogen was of the type (A) and type (I) of amorphous oil generated matter according to the two adopted classification methods [8, $13]$.

In addition, the value of S2 for Yamama Formation at the depth of $3585 \mathrm{~m}$ in well Su-8 was 12.1, whereas the HI value was 720 and PI value was 0.34 . The rocks of the formation are considered as having a low thermal maturation, where the value Tmax was $428 \mathrm{C}^{\circ}$. It is important to mention here that in spite of the fair organic content in Yamama Formation, its ability to produce hydrocarbons is high Figures-(2-6).

\section{Conclusions}

From the geochemical and palynological studies of Nahr Umr, Zubair and Yamama Formations rocks wells (Su-14, Su-9 and Su-8) respectively, in the Subba oil field, we have drawn a number of conclusions. The rocks of Nahr Umr Formation are rich source rocks. They have kerogen of type (II), 
whereas the dominant amorphous organic matter is of type (A). These rocks are thermally immature and contain very good levels of organic production. The rocks of Zubair Formation are rich, with kerogen of types (I \& II/III) and AOMs of types (A\&D); they have low thermal maturation, contain good to very good total organic matter, and have the ability to produce liquid hydrocarbons. The rocks of Yamama Formation are considered as rich source rocks, they have kerogen of type (I) with the dominant AOM of type (A). They contain a good abundance of TOC, having low thermal maturation and an ability to produce hydrocarbons. The organic facies analyses of the sediments of Yamama, Zubair and Nahr Umr Formations showed the presence of two palynofacies. The first palynofacies is composed of distal suboxic-anoxic basin palynofacies, characterized by low to medium presence of palynologies and the dominance of amorphous organic matter in Yamama Formation and part of Zubair Formation. The second palynofacies is the distal dysoxic-oxic shelf palynofacies, which is characterized by the dominance of amorphous organic matter with little presence to absence of palynologies, which are represented by Nahr Umr Formation and part of Zubair Formation.

\section{References}

1. Buday, T. 1980. The regional geology of Iraq; Stratigraphy and Palaeogeography, State Organization for Minerals, Baghdad, V.1, 445 P.

2. Pitman, J. K., Steinshouer, D. and Lewan, M. D. 2004. Petroleum generation and migration in the Mesopotamian Basin and Zagros Fold Belt of Iraq: results from a basin-modeling study, GeoArabia, V.9 No.4, Gulf Petrolink Bahrain, pp.41-72.

3. Basrah Oil Company (BOC) - Unpublished Final Reports.

4. Barss, M. S. and William, G. L., 1977. Palynology and Nanofossils processing techniques, Geol. Survey. Canada. Paper 73-26, (25 P).

5. Tyson, R.V. 1995. Sedimentary organic matter; Organic Facies and Palynofacies: Chapman Hall, London, $615 \mathrm{P}$.

6. Stein, R. 1986. Organic carbon and sedimentation rate-further evidence for anoxic deep-water conditions in the Cenomanian / Turonian Atlantic Ocean: Marine Geology, 72: 199-209.

7. Peters, K. E. and Cassa, M. R. 1994. Applied Source Rock Geochemistry, in the petroleumsystem from source to trap (Magoon L.B. and W.G. Dow, eds). American Association of petroleum Geologist, Tulsa, Ok, pages, 40: 93-117.

8. Thompson, C. L. and Dembicki, H. J. R. 1986. Optical characteristics of amorphous Kerogen and the hydrocarbon-generation potential of source rocks, International Journal of Coal Geology, 6: $229-249$.

9. Nasser, N.D. and McCulloh, T.H. 1989. Thermal history of sedimentary basin methods and case histories. Springer-Verlag, New York. 400 P.

10. Mao, S., Eglinton, L. B., Whelan, J. and Liu, L. I. 1994. Thermal evolution of sediments from leg 139, middle valley, Juan de Fuca Ridge: an organic petrological study, In Motti, M.J., Davis, E.E., Fisher, A.T., and Slack, J.F. (eds), Proceeding of the Ocean Drilling Program, Scientific results,V.139, pp.495-508.

11. Staplin, F. L. 1969. Sedimentary organic matter, organic metamorphism, and oil and gas occurrence. Bulletin of Canadian Petroleum Geology, 17: 47-66.

12. Van Gijzel, P. 1982. Characterization and identification of kerogen and bitumen and determination of thermal maturation by means of qualitative and quantitative microscopical techniques. Soc. Econ. Paleontology. Mineral, Short Course Notes. 7: 159-216.

13. Tissot, B.P. and Welte, D. H. 1984. Petroleum formation and occurrence: Anew approach to oil and gas exploration, Springer-Verlag, Berlin, $699 \mathrm{P}$.

14. Waterhouse, H. K. 1995. High-resolution Palynofacies investigation of Kimmeridgian sedimentary cycles, House, M.R. \& Geology, A.S. (eds): Orbital forcing Timescales and cyclostratigraph-Geology Soc. Spec. Publ. No.85, pp.75-114.

15. Batten, D. J. 1996. Mesozoic - Tertiary spores and Pollen 206 - Upper Jurassic and Cretaceous Miospores, Jansonius, J, McGregor DC (eds), Palynology: Principles and applications American Association of Stratigraphic Palynologistis Foundation, 2: 807- 830. 